\title{
The relationship between body composition and diatary habits in the university faculty members
}

\section{Fatma ARSLAN ${ }^{1}$, Ozden TASGIN², Sefika Dilek GUVEN³, Aysegul OZCAN³, Ozen OZBAY OZBAS ${ }^{4}$}

\author{
${ }^{1}$ Necmettin Erbakan University, Department of Recreation Management, Konya, Turkey. \\ ${ }^{2}$ Nevşehir Hacı Bektaş Veli University, Department of Educational Sciences, Nevşehir, Turkey. \\ ${ }^{3}$ Nevşehir Hacı Bektaş Veli University, Department of Nursing, Nevşehir, Turkey. \\ ${ }^{4}$ Aksaray University, Department of Food Engineering, Aksaray, Turkey. \\ Address correspondence to S. D. Guven, e-mail: sdguven@nevsehir.edu.tr \\ The paper was presented at the 12th International Scientific Conference on Transformation Process in Sport "Sport Performance" Montenegrin Sports \\ Academy in Podgorica - Montenegro on the 2nd - 5th April 2015.
}

\begin{abstract}
The aim of this study was to determine the relationship between eating habits and body composition of the university personnels. The sampling of this research consisted of academic and administrative personnels from the university (68 female and 124 male personnels). Body weight and composition were measured with a Tanita instrument. Data were collected by performing a questionnaire including 33 items. For the statistical analysis, frequency and percentage (\%) distributions, ChiSquare test and Pearson correlations were used. For females, $38.9 \%$ of the university members, $30 \%$ of the instructors and $32.5 \%$ of the administrative personnels and for men, $31.6 \%$ of the university members, $38.5 \%$ of the instructors and $27.2 \%$ of the administrative personnels had two meals in a day. Both female and male administrative personnels had more junk food consumption than the others. In this study, there was more fat milk/yogurt consumption that was correlated with body composition parameters in the female university members $(\mathrm{p}<0.05)$. This study showed that the participants generally had unhealthy lifestyles and the critical values in waist circumferences and hip circumferences, waist-height ratio, and waist-hip ratio from body composition parameters. Because of this, healthy lifestyles-associated behaviors (exercises, physical activities, dietary habits and responsibilities of health, e.g.) must be developed among the university faculty members and other employees.
\end{abstract}

Keywords: Body composition, eating habits, university employees.

\section{INTRODUCTION}

For taking nutrition, growing up, keeping on life and protecting health, necessary foods are required (5). Nutrition is both a physiological and psychosocial event and varies under many factors (16). Work life plays highly important roles in eating style and individuals' working conditions affect their health (9). Many factors such as types of works, workplace, working environment, work load, etc. are effective in the development of eating pattern (13). Work intensity and its related stress have impacts on individuals' nutrition (24). When personnels do not eat properly and keep a balanced diet, their health gets worse, their resistance to diseases reduce, their attention decreases, their movements slow down, their absence from work increases, required productivity is not given and production goes down. Personnels' nutrition problems are resulted in workday losses, occupational diseases, occupational accidents and increasing health expenses. Eating properly and keeping a balanced diet support personnels to be healthy and they contribute to increase work production (17). Topic-related studies show that eating properly and keeping a balanced diet in personnels increase personnels' efficiency and productivity, minimize diseases and occupational diseases, improve personnels' health, reduce absence from work, strengthen work place psychology, work peace and tranquility, increase personnels' resistance to diseases $(15,19)$. For these reasons, the determination of relations between working individuals' eating habits and body compositions is substantial for both protecting physical health and 
making contributions to improve work peace, personnels'productivity by arranging personnels' eating habits. The purpose of the study is to analyze the effects of body structures and eating habits of personnels working in the university on work life and to enrich the literature about the significance of diet habits.

\section{MATERIALS \& METHODS}

This research is a descriptive study for the determination of relations between eating habits and body compositions of working individuals.

This research was done at the university in the Central Anatolian Region of Turkey in SeptemberNovember, 2014. In the relevant university, total 654 personnels including 429 academic personnels and 225 managing personnels were assigned. Sixty eight females, 124 male personnels agreed to participate in the study, the sampling group consisted of them. The participant personnels were divided into two groups: education background and work situation.

The female university members $(\mathrm{n}=18)$, the male university members $(n=19)$, the female instructors $(n=10)$, the male instructors $(n=13)$, the female managing personnels $(\mathrm{n}=40)$, the male managing personnels $(\mathrm{n}=92)$. In this research, lecturers, research assistants, instructors and personnels included in expert staff were assessed in the group of instructors.

For carrying out this research, the institution and the participants were received approval.

In collection of data, the relevant questionnaire form consisted of 33 questions aimed at determining individuals' sociodemographical features and eating habits, and body composition measurement registration fields. The questionnaire forms were filled by the researchers with the face to face method and their body composition measurements were done by the researchers.

\section{Body composition measurements}

\section{Height and body weight measurement}

The participants' body weights were measured with the Tanita (model TBF-305; Tanita, Arlington Heights, IL) body composition analyser as kilogram, their heights were measured with a rigid measure as well. Height measurements were done without shoes, feet next to each other.

\section{Body mass index (BMI)}

$\mathrm{BMI}$ is the ratio of the body weight in kilograms $(\mathrm{kg})$ by the square of height in meters (BMI= weight $(\mathrm{kg}) / \operatorname{boy}^{2}\left(\mathrm{~m}^{2}\right)$. Their height was entered in the Tanita body composition analyzer, determined by the analyzer.

BMI was categorized in accordance with the World Health Organization (WHO) criteria. $<18.5 \mathrm{~kg} /$ $\mathrm{m}^{2}$ as weak, $18.5-24.9 \mathrm{~kg} / \mathrm{m}^{2}$ as normal, $25.0-29.9$ $\mathrm{kg} / \mathrm{m}^{2}$ as some fatter, $30.0-39.9 \mathrm{~kg} / \mathrm{m}$ as fat, $>40.0 \mathrm{~kg} /$ $\mathrm{m}^{2}$ as highly fatter were taken (22).

\section{Estimation of body fat percentage}

Body fat percentage was determined with the Tanita body composition analyser.

\section{Waist-hip ratio (WHR)}

The measurements were done with a rigid measurement. Waist circumference was measured from the thinnest part of the area between the lowest rib and crista iliac. Hip circumference was measured from the trochanter major. From both measurement results, waist-hip ratio was estimated. WHO' waist circumference, waist-hip ratio reference values; waist circumference in males $\geq 94 \mathrm{~cm}$, in females $\geq 80 \mathrm{~cm}$, risk of metabolic complication, in males $\geq 102 \mathrm{~cm}$, in females $\geq 88 \mathrm{~cm}$ high risk of metabolic complication, waist - hip ratio in males $\geq 0.95 \mathrm{~cm}$, in females $\geq 0.85$ $\mathrm{cm}$ high risk of metabolic complication (22).

\section{Waist-height ratio (WHRT)}

Waist-height ratio is estimated as waist circumference $(\mathrm{cm}) /$ height $(\mathrm{cm})$. Waist-height ratio is considered to be a better scale rather than waist circumference and BMI in scanning adult cardiometabolic risk factors. When waist circumference- height ratio is over 0.5 and below 0.4 , metabolic disease risk occurs (3).

\section{Analysis of data}

Data Coding and their statistical analysis were done with the SPSS 12.0 package program on computer. In evaluation of data, chi-square test to see whether there was a relation between mean, standard deviation, percentage values, two or more variables and Pearson correlation analysis to test the relation of one variable with two or more variables were used.

\section{RESULTS}

In this research, the females had an average age of $30.85 \pm 7.07$, the males had mean age of $34.85 \pm 7.40$, the females had mean height of $1.63 \pm 0.06$, the males had mean height of $1.75 \pm 0.09$, the females had an average body weight of $60.48 \pm 10.51$, and the males had mean body weight of $82.86 \pm 13.25$ (Table 1 ). 
Table 1. Personnels' descriptive characteristics.

\begin{tabular}{llccc}
\hline Characteristics & Gender & $\mathrm{n}$ & Mean & SD \\
\hline Age & Female & 68 & 30.85 & 7.07 \\
& Male & 124 & 34.85 & 7.40 \\
Height & Female & 68 & 1.63 & 0.06 \\
& Male & 124 & 1.75 & 0.09 \\
Body Weight & Female & 68 & 60.48 & 10.51 \\
& Male & 124 & 82.86 & 13.25 \\
\hline
\end{tabular}

Table 2. Distribution of personnels' descriptive characteristics in accordance with work situation.

\begin{tabular}{lllccc}
\hline Work Situation & Gender & Variables & $\mathrm{n}$ & Mean & SD \\
\hline University Members & Female & Age & 18 & 36.83 & 5.17 \\
& & Body Weight & 18 & 63.37 & 12.46 \\
& Male & Height & 18 & 162.11 & 6.07 \\
& & Age & 19 & 40.57 & 6.36 \\
& Body Weight & 19 & 85.32 & 11.40 \\
Instructors* & Female & Height & 19 & 175.47 & 6.35 \\
& & Age & 10 & 28.50 & 1.65 \\
& \multirow{4}{*}{ Male } & Body Weight & 10 & 58.85 & 10.10 \\
& & Height & 10 & 162.60 & 5.97 \\
& & Bge & 13 & 36.00 & 6.92 \\
Managing Personnels & Female & Height & 13 & 83.67 & 18.02 \\
& & Age & 13 & 172.53 & 8.65 \\
& & Body Weight & 40 & 28.75 & 7.15 \\
& & Height & 40 & 162.80 & 6.56 \\
& Male & Age & 92 & 33.50 & 7.13 \\
& & Body Weight & 92 & 82.23 & 12.92 \\
& & Height & 92 & 174.73 & 9.84 \\
\hline
\end{tabular}

* Lecturer, research assistant, instructor and personnels included in expert staff.

When the personnels' descriptive characteristics were analyzed in their distributions in accordance with work situation, among the university members, the mean age was $36.83 \pm 5.17$ in the females, $40.57 \pm 6.36$ in the males, the mean body weight was $63.37 \pm 12,46$ in the females, $85.32 \pm 11.40$ in the males, the mean height was $162.11 \pm 6.07$ in the females, $175.47 \pm 6.35$ in the males; among the instructors, the mean age was $28.50 \pm 1.65$ in the females, $36.00 \pm 6.92$ in the males, the mean body weight was $58.85 \pm 10.10$ in the females, $83.67 \pm 18.02$ in the males, the mean height was $162.60 \pm 5.97$ in the females, $172.53 \pm 8.65$ in the males; among the managing personnels, the mean age was $28.75 \pm 7.15$ in the females, $33.50 \pm 7.13$ in the males, the mean body weight was $59.59 \pm 9.65$ in the females, $82.23 \pm 12.92$ in the males, the mean height was $162.80 \pm 6.56$ in the females, $174.73 \pm 9.84$ in the males (Table 2).

When the personnels' body composition values were examined in gender, the averages of BMI, fat mass, fat-free mass, body water ratio, hip circumference, waist circumference, waist-hip ratio, waist-height ratio, systolic blood pressure and diastolic blood pressure values were higher in the males rather than the females, the difference between body composition values and gender except for fat mass was regarded to be statistically significant $(\mathrm{p}<0.05 ;$ Table 3$)$.

Considering the waist-hip ratio and waist-height ratio averages in accordance with the personnels' exercise performance, these averages were higher in the managing personnels doing regular exercises 
rather than other personnels, the waist-hip ratio in the managing personnels not doing exercises, the waist-height ratio in the lecturers were higher rather than the other personnels (Figure 1).

While $5.6 \%$ of the female lecturers, $20.0 \%$ of the instructors ate three meals, the female managing personnels were observed not to eat three meals. 3.3\% of the male managing personnels ate three meals but the university members and the instructors were also observed not to eat three meals. The differences in the male personnels' meal numbers resulting from gender and work situation were statistically significant $(\mathrm{p}<0.05$; Table 4$)$.

Table 3. Personnels' body composition values in accordance with their gender.

\begin{tabular}{llcccc}
\hline Body Composition & Gender & $\mathrm{n}$ & Mean & SD & Test \\
\hline BMI & Female & 68 & 22.86 & 3.58 & $\mathrm{Z}=-6.581$ \\
& Male & 124 & 27.40 & 6.56 & $\mathrm{p}=0.000$ \\
Fat Percentage & Female & 68 & 27.41 & 8.07 & $\mathrm{Z}=-5.179$ \\
& Male & 124 & 21.05 & 7.19 & $\mathrm{p}=0.000$ \\
Fat Mass & Female & 68 & 17.31 & 7.52 & $\mathrm{Z}=-0.683$ \\
Fat-Free Mass & Male & 124 & 18.00 & 7.81 & $\mathrm{p}=0.495$ \\
Body Water Ratio & Female & 68 & 43.19 & 4.35 & $\mathrm{Z}=-10.800$ \\
& Male & 124 & 64.92 & 8.46 & $\mathrm{p}=0.000$ \\
Hip Circumference & Female & 68 & 31.62 & 3.18 & $\mathrm{Z}=-10.985$ \\
& Male & 124 & 48.33 & 11.06 & $\mathrm{p}=0.000$ \\
Waist Circumference & Female & 68 & 96.46 & 9.28 & $\mathrm{Z}=-6.021$ \\
& Male & 124 & 104.13 & 7.69 & $\mathrm{p}=0.000$ \\
Waist-Hip Ratio & Female & 68 & 78.99 & 11.21 & $\mathrm{Z}=-8.218$ \\
& Male & 124 & 96.01 & 10.53 & $\mathrm{p}=0.000$ \\
Waist-Height Ratio & Female & 68 & 0.82 & 0.12 & $\mathrm{Z}=-8.946$ \\
& Male & 124 & 0.92 & 0.06 & $\mathrm{p}=0.000$ \\
Systolic Blood Pressure & Female & 68 & 0.49 & 0.07 & $\mathrm{Z}=-2.686$ \\
\multirow{2}{*}{ Diastolic Blood Pressure } & Female & 68 & 115.18 & 12.31 & $\mathrm{Z}=-4.773$ \\
& Male & 124 & 0.55 & 0.07 & $\mathrm{p}=0.000$ \\
& Male & 124 & 78.81 & 11.46 & $\mathrm{Z}=-3.236$ \\
& & & & & $\mathrm{p}=0.001$ \\
\hline & & 124.67 & 14.68 &
\end{tabular}

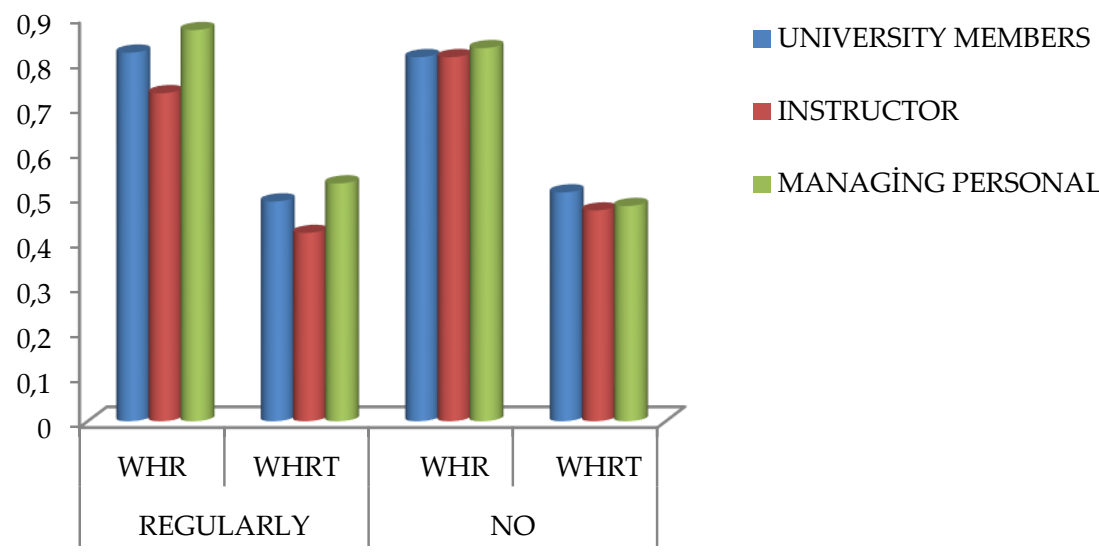

Figure 1. Waist-hip ratio and waist-height ratio averages in accordance with personnels' exercise performance. 
Table 4. Chi-Square test results of personnels' meal numbers in accordance with gender and work situation.

\begin{tabular}{|c|c|c|c|c|c|c|c|c|}
\hline \multicolumn{2}{|c|}{ Daily meal numbers } & \multicolumn{3}{|c|}{$\begin{array}{l}\text { University } \\
\text { Members }\end{array}$} & \multirow{2}{*}{$\begin{array}{c}\text { Instructors } \\
2\end{array}$} & \multicolumn{3}{|c|}{$\begin{array}{l}\text { Managing } \\
\text { Personnels } \\
\end{array}$} \\
\hline \multirow{10}{*}{ Female } & One Meal & $\mathrm{n}$ & 5 & & & & 9 & \\
\hline & & $\%$ & 27.8 & & 20 & & 22.5 & \\
\hline & Two Meals & $\mathrm{n}$ & 7 & & 3 & & 13 & \\
\hline & & $\%$ & 38.9 & & 30 & & 32.5 & \\
\hline & Three Meals & $\mathrm{n}$ & 1 & $X^{2}=4.308$ & 2 & $X^{2}=0.286$ & - & $X^{2}=0.727$ \\
\hline & & $\%$ & 5.6 & $\mathrm{p}=0.116$ & 20 & $\mathrm{p}=0.867$ & - & $\mathrm{p}=0.394$ \\
\hline & Four Meals & $\mathrm{n}$ & - & & - & & - & \\
\hline & & $\%$ & - & & - & & - & \\
\hline & Total & $\mathrm{n}$ & $\mathrm{n}$ & & 7 & & 22 & \\
\hline & & $\%$ & $\%$ & & 70 & & 55 & \\
\hline \multirow[t]{10}{*}{ Male } & One Meal & $\mathrm{n}$ & 6 & & 5 & & 25 & \\
\hline & & $\%$ & 31.6 & & 38.5 & & 27.2 & \\
\hline & Two Meals & $\mathrm{n}$ & 4 & & 2 & & 11 & \\
\hline & & $\%$ & 21.1 & & 15.4 & & 12 & \\
\hline & Three Meals & $\mathrm{n}$ & - & $X^{2}=0.400$ & - & $X^{2}=1.286$ & 3 & $X^{2}=37.732$ \\
\hline & & $\%$ & - & $\mathrm{p}=0.527$ & - & $\mathrm{p}=0.867$ & 3.3 & $\mathrm{p}=0.000$ \\
\hline & Four Meals & $\mathrm{n}$ & - & & - & & 1 & \\
\hline & & $\%$ & - & & - & & 1.1 & \\
\hline & Total & $\mathrm{n}$ & $\mathrm{n}$ & & 7 & & 10 & \\
\hline & & $\%$ & $\%$ & & 53.8 & & 43.5 & \\
\hline
\end{tabular}

Table 5. Chi-Square test results of personnels' fast food consumption in accordance with gender and work situation.

\begin{tabular}{|c|c|c|c|c|c|c|c|c|}
\hline \multicolumn{2}{|c|}{ Fast food consumption } & $\begin{array}{l}\mathrm{n} \\
\%\end{array}$ & $\begin{array}{l}\text { University } \\
\text { Members }\end{array}$ & & $\begin{array}{c}\text { Instructor } \\
\mathrm{s} \\
\end{array}$ & $\mathrm{p}$ & $\begin{array}{l}\text { Managing } \\
\text { Personnel }\end{array}$ & $\mathrm{p}$ \\
\hline \multirow{12}{*}{ Female } & \multirow{4}{*}{$\begin{array}{l}\text { 3-5 times in a } \\
\text { week } \\
\text { Once in a week }\end{array}$} & $\mathrm{n}$ & - & & 2 & & 1 & \\
\hline & & $\%$ & - & & 20 & & 2.5 & \\
\hline & & $\mathrm{n}$ & 7 & & 1 & & 8 & \\
\hline & & $\%$ & 38.9 & & 10 & & 20 & \\
\hline & \multirow[t]{2}{*}{ Once in 15 days } & $\mathrm{n}$ & 3 & & 3 & & 9 & \\
\hline & & $\%$ & 16.7 & $X^{2}=2.444$ & 30 & $\mathrm{X}^{2}=2.000$ & 22.5 & $X^{2}=20.750$ \\
\hline & \multirow[t]{2}{*}{ Once a month } & $\mathrm{n}$ & 5 & $\mathrm{p}=0.485$ & 4 & $\mathrm{p}=0.572$ & 18 & $\mathrm{p}=0.000$ \\
\hline & & $\%$ & 27.8 & & 40 & & 45 & \\
\hline & \multirow[t]{2}{*}{ Non-Consuming } & $\mathrm{n}$ & 3 & & - & & 4 & \\
\hline & & $\%$ & 16.7 & & - & & 10 & \\
\hline & \multirow[t]{2}{*}{ Total } & $\mathrm{n}$ & $\mathrm{n}$ & & 10 & & 40 & \\
\hline & & $\%$ & $\%$ & & 100 & & 100 & \\
\hline \multirow{12}{*}{ Male } & \multirow{4}{*}{$\begin{array}{l}\text { 3-5 times in a } \\
\text { week } \\
\text { Once in a week }\end{array}$} & $\mathrm{n}$ & 2 & & - & & 7 & \\
\hline & & $\%$ & 10.5 & & - & & 7.6 & \\
\hline & & $\mathrm{n}$ & 3 & & 3 & & 14 & \\
\hline & & $\%$ & 15.8 & & 23.1 & & 15.2 & \\
\hline & \multirow[t]{2}{*}{ Once in 15 days } & $\mathrm{n}$ & 3 & & 4 & & 12 & \\
\hline & & $\%$ & 15.8 & $X^{2}=2.842$ & 30.8 & $X^{2}=2.692$ & 13 & $X^{2}=39.849$ \\
\hline & \multirow[t]{2}{*}{ Once a month } & $\mathrm{n}$ & 6 & $\mathrm{p}=0.585$ & 5 & $\mathrm{p}=0.442$ & 42 & $\mathrm{p}=0.000$ \\
\hline & & $\%$ & 31.6 & & 38.5 & & 45.7 & \\
\hline & \multirow[t]{2}{*}{ Non-consuming } & $\mathrm{n}$ & 5 & & 1 & & 17 & \\
\hline & & $\%$ & 26.3 & & 7.7 & & 18.5 & \\
\hline & \multirow[t]{2}{*}{ Total } & $\mathrm{n}$ & 19 & & 13 & & 92 & \\
\hline & & $\%$ & 100 & & 100 & & 100 & \\
\hline
\end{tabular}

Among the female university members, fast food consumption was in $38.9 \%$ of the university members once in a week, in $40.0 \%$ of the university members and $45.0 \%$ of the managing personnels once in a month, fast food consumption was also once in a month by $31.6 \%$ of the male university members, by
$38.5 \%$ of the instructors and by $45.7 \%$ of the managing personnels. Our research indicated that the relation between personnels' fast food consumption, gender and work situation was statistically significant $(\mathrm{p}<0.05$; Table 5$)$. 
Table 6. Correlation analysis in personnels' full fat milk and yogurt consumption and body compositions.

\begin{tabular}{lccc} 
Full fat milk/yogurt consumption & $\mathrm{n}$ & $\mathrm{r}$ & $\mathrm{P}$ \\
\hline Body Weight & 18 & 0.61 & $0.008^{*}$ \\
BMI & 18 & 0.62 & $0.006^{*}$ \\
Fat Percentage & 18 & 0.54 & $0.022^{*}$ \\
Fat Mass & 18 & 0.58 & $0.012^{*}$ \\
Fat-Free Mass & 18 & 0.59 & $0.010^{*}$ \\
Waist Circumference & 18 & 0.55 & $0.018^{*}$ \\
Waist-Hip Ratio & 18 & 0.50 & $0.034^{*}$ \\
Waist-Weight Ratio & 18 & 0.50 & $0.033^{*}$ \\
\hline * p<0.05 & & &
\end{tabular}

A positively significant relation was found between full fat milk and yogurt consumption and body compositions ( $\mathrm{p}<0.05$; Tablo 6 ).

\section{DISCUSSION}

The prevalance of obesity has been increasing all over the world day by day (1). When BMI reaches 25 and over it, the risks of hypertension, type 2 Diabetes Mellitus and cardiovascular diseases concerning the obesity degree show increases (8). According to the Turkey Nutrition and Health Research 2010 (4) results, BMI average was found to be $26.4 \pm 4.5$ in males aged 19 and over, $28.9 \pm 6.4$ in females. Ulaş \& Genç (20) compared the BMI values in gender within their study, the males' BMI values were considered to be significantly higher than the females' ones. Berkel's research (6) showed that the participant female academic staff's BMI average was 22.89, the males' one was 26.15. This research found that the male personnels' BMI average was $27.40 \pm 6.56$ (Table 3). Hereby, we can say that the adult males are fatter/more weighted, so they have risks of hypertension, type 2 Diabetes Mellitus and cardiovascular diseases.

The waist circumference and waist/hip ratio are used for the risk evaluation in chronical diseases among the adults (13). The waist/hip ratio assses abdominal obesity (11). Abdominal obesity is more closely related with metabolic complications rather than BMI. According to the Turkey Nutrition and Health Research 2010 (4) results, the waist circumference was $>102 \mathrm{~cm}$ in $24.8 \%$ of males aged 19 and over, $>88 \mathrm{~cm}$ in $53.9 \%$ of females. This research determined that the females' waist circumference was $78.99 \pm 11.21$, the males' ones $96.01 \pm 10.53$ (Table 3). Hereby, we can say that males have risks of metabolic complication. Also, the females' waist/hip ratio was $0.82 \pm 0.12$, the males' one was $0.92 \pm 0.06$ in our study. The result of the study shows the participant individuals were below the risk values of metabolic complication.

The waist/height ratio is seemed to be a better scale rather than the waist circumference and BMI in scanning cardiometabolic risk factors in adults. When the waist circumference / height ratio is over 0.5 and below 0.4, the metabolic disease risk occurs (3). According to the Turkey Nutrition and Health Research 2010 (4) results, the waist/height ratio was 0.59 in females aged 19 and over, 0.55 in males. From this research, it was seen that waist/height ratios of all workers were over 0.50 . So it can be said that all personnels under the risk of metabolic disease.

Regular activities have positive effects on body composition as well as health (10). Energy expenditures develop due to activities, so decreases are seen in body weight and other measurements (18). Özenoğlu et al. (12) suggested that the females' waist-height ratio was $0.52 \pm 0.7$ before exercises, it was $0.51 \pm 0.6$ after exercises in their research about females. Concerning the personnels' exercise performance herein, waist-hip ratio and waist-height ratio averages were higher in the managing personnels doing regular exercises rather than the other personnels, waist-hip ratio in the managing personnels not doing exercises and waist-height ratio in the university members were regarded to be higher than the other personnels (Figure 1).

Eating habits such as meal skip, short or long periods between meals influence metabolism, thus human health. When daily meal number is below three, it causes undesirable metabolic changes in any organism (2). Berkel's research (6) indicated that $69.4 \%$ of the university members working in the university consumed three main meals in a day, $70.9 \%$ of them skipped a meal. Ulaş \& Genç (20) presented that $57.4 \%$ of the personnels assigned in the military hospital skipped a meal. While $5.6 \%$ of the female university members and $20.0 \%$ of the instructors ate three meals, the female managing personnels did not eat three meals. $3.3 \%$ of the male managing personnels ate three meals, however, the university members and the instructors were determined not to eat three meals. The differences in the male personnels' meal numbers from gender and work situation were regarded to be statistically significant $(\mathrm{p}<0.05 ;$ Table 4$)$. In this regard, the female managing personnels, the male university members and the instructors' daily meal numbers were below three, that's why, undesirable metabolic changes are likely to ocur in their organisms. 
When consuming fast food products, insufficient nutrients or excessive nutrients are available in menus. This situation triggers chronic diseases such as obesity, diabetes, cardiovascular diseases and cancer (7). Berkel's paper (6) showed that $37.7 \%$ of university members working in the university consumed fast food products once in a month and more scarcely. From this research, it was clear that fast food consumption was once in a week by $38.9 \%$ of the female university members, once in a month by $40.0 \%$ of the instructors and $45.0 \%$ of the managing personnels, once in a month by $31.6 \%$ of the male university members, $38.5 \%$ of the instructors and $45.7 \%$ of the managing personnels. This research indicated that there was a statistically significant difference between the personnels' fast food consumption, gender and work situation $(\mathrm{p}<0.05)$ (Table 5). Since increasing fast food consumption becomes a part of modern life, personnels are considered to eat fast food products, and for this reason, risks of metabolic diseases are regarded to increase as well.

An adult who consumes two glasses of milkyogurt in a day, meets the half of daily calcium need. Milk products are rich in saturatiod fat and cholesterol. Adult individuals who are required to limit fat and cholesterol intake, must prefer fat-free and fat-reduced milk, yogurt and cheese varieties (25). Uzunöz \& Gülşen's research (21) determined that from the university students, $13.33 \%$ consumed fat-free yogurt, $43.67 \%$ consumed low-fat yogurt, $25.0 \%$ consumed fat yogurt and $18.0 \%$ also consumed full-fat yogurt. Zemel's research (26) represented that there was $22 \%$ more weight loss and $61 \%$ more body fat loss in the group eating $170 \mathrm{~g}$ portion of fat-free yogurt in a day during 12 weeks rather tha in the control group. In this research, a positively significant relation was found between full-fat milk and yogurt consumption and body composition ( $\mathrm{p}<0.05$; Table 6 ). This result indicates that body composition values increase when full-fat milk and yogurt consumption increase.

According to the results of this research, it can be said that the staff working in university keep an unhealthy diet. Eating properly and keeping a balanced diet are effective for protecting body composition. That's why, university personnels are required to join in necessary activities in order to have healthy lifestyles (exercises, physical activities, diet habits and health responsibilities).

\section{REFERENCES}

1. Akbulut G, Özmen M, Besler T. Çağın hastalığı obezite. TÜBİTAK Bilim ve Teknik Dergisi, 2007; 2(7): 5-12.

2. Arslan P, Karaağaoğlu N, Duyar Y, Güleç E. Yüksek öğrenim gençlerin beslenme alışkanlıklarının puanlandırma yöntemi ile değerlendirilmesi. Beslenme ve Diyet Dergisi, 1994; 22: 195208.

3. Ashwell M, Gunn P, Gibson S. Waist-to-height ratio is a better screening tool than waist circumference and BMI for adult cardiometabolic risk factors: systematic review and metaanalysis. Obes Rev, 2012; 13(3):275-286.

4. Bakanlığı T S. Türkiye Beslenme ve Sağlık Araştırması 2010: Beslenme durumu ve alışkanlıklarının değerlendirilmesi sonuç raporu. Ankara, Sağlık Bakanlığı Sağlık Araştırmaları Genel Müdürlüğü. T.C. Sağlık Bakanlığı Yayın No: 931, 2014: 480 .

5. Baysal A. Beslenme. Ankara, Hatiboğlu Basım ve Yayım San. Tic. Ltd. Şti, 2009: 560.

6. Berkel M. Trakya Bölgesi'ndeki üniversitelerde çalışan akademik personelin beslenme alışkanlıkları üzerine bir araştırma. T.C. Namık Kemal Üniversitesi Fen Bilimleri Enstitüsü Yüksek Lisans Tezi. 2011.

7. Güleç M, Yabancı N, Göçgeldi E, Bakır B. Ankara'da iki kız öğrenci yurdunda kalan öğrencilerin beslenme alışkanlıkları. Gülhane Tıp Dergisi, 2008; 50(2): 102-109.

8. Kalan I. Yeşil Y. Obezite ile İlişkili Kronik Hastalıklar. MisED, 2010; 23- 24(1): 78-81.

9. Lallukka T, Sarlio-Lähteenkorva S, Roos E, Laaksonen M, Rahkonen O, Lahelma E. Working conditions and health behaviours among employed women and men: the Helsinki Health Study. Preventive medicine, 2004; 38(1): 48-56.

10. Matsuoa T, Okura T, Nakata Y, Yabushita N, Numaoa S, Sasai $\mathrm{H}$, Tanaka $\mathrm{K}$. The influence of physical activity-induced energy expenditure on the variance in body weight change among individuals during a diet intervention. Obesity Research \& Clinical Practice, 2007; 1(2): 109-117.

11. Onat A. Türkiye'de obezitenin kardiyovasküler hastalıklara etkisi. Türk Kardiyoloji Derneği Arşivi, 2003; 31(5): 279-289.

12. Özenoğlu A, Uzdil Z, Sevde Y. Kadınlarda Tek Başına Planlı Egzersizin Antropometrik Ölçümler ve Vücut Kompozisyonu Üzerine Etkisi. Samsun Sağlık Bilimleri Dergisi, 2016; 1(1): 110.

13. Pekcan G. Beslenme durumunun saptanmasi. Diyet El Kitabi. Hatipoğlu Yayınevi. Ankara, 2008: 67-141.

14. Proper K, Van Mechelen W. (2008). Effectiveness and economic impact of worksite interventions to promote physical activity and healthy diet. Geneva: World Health Organization. http://www.who.int/dietphysicalactivity/Proper_K.pdf?ua=1

15. Saltık A. Çağdaş Sağlık Anlayışı Bağlamında İşçi Beslenmesi. Beslenme ve Diyet Dergisi, 1995; 24(1): 123-149.

16. Salvy SJ, Jarrin D, Pakich R, Irfan N, Pliner P. Effects of social influence on eating in couples, friends and strangers. Appetite, 2007; 49(1): 92-99.

17. Sözen S, Bilir N, Yıldız AN, Yıldız E, Sözen T. Metal sektöründe bir işyerinde çalışanların beslenme alışkanlıkları ve ilişkili antropometrik ölçümleri. Toplum Hekimliği Bülteni, 2009; 28(3): 7-14. 
18. Swift DL, Johannsen NM, Lavie CJ, Earnest CP, Church TS. The Role of Exercise and Physical Activity in Weight Loss and Maintenance. Progress in Cardiovascular Diseases, 2014; 56 (4): 441-447.

19. Tanır F, Şaşmaz T, Beyhan Y, Bilici S. Doğankent Beldesinde Bir Tekstil Fabrikasında Çalışanların Beslenme Durumu. Türk Tabipler Birliği Mesleki Sağlık ve Güvenlik Dergisi, 2001: 2225.

20. Ulaş B, Genç MF. Malatya Asker Hastanesinde 2007 yılında görev yapan personelin sağlıklı beslenme konusundaki tutum ve davranışları. Turgut Özal Tıp Merkezi Dergisi, 2010; 17(3): 187-193.

21. Uzunöz M, Gülşen M. Üniversite öğrencilerinin süt ve süt ürünleri tüketim alışkanlıklarının belirlenmesi. Gıda Teknolojileri Elektronik Dergisi, 2007; 3: 15-21.
22. WHO. Global database on BMI. WHO, 2004 (http://apps.who.int/bmi/index.jsp?introPage=intro_3.html). Erişim tarihi: 20.03.2017

23. WHO, Waist Circumference and Waist-hip ratio: report of a WHO expert consultation, Annex A: Current uses of waist circumferences and waist-hip ratios, and recommended cutoff points. Geneva, 8-11 December, 2008: 34

24. Yemişçi D, Pekcan G. İstanbul İlinde Farklı İş Yerlerinde Çalışan Yetişkin Bireylerin Beslenme Örüntüsünün Saptanmas1. Beslenme ve Diyet Dergisi, 2012; 40(2):136-148.

25. Yücecan S. Optimal beslenme. Sağlık Bakanlığı Temel Sağlık Hizmetleri Genel Müdürlüğü Beslenme ve Fiziksel Aktiviteler Daire Başkanlığı, Ankara, Klasmat Matbaacılık, 2012: 14.

26. Zemel MB. The role of dairy foods in weight management. Journal of the American College of Nutrition, 2005; 24(sup6): 537-546. 